summer schools. Every three years, the Section holds a general conference of Czech and Slovak physicists (the next - the 12th takes place in 1996 in Ostrava). The Section also organizes national meetings on more topical subjects such as science and technolgy policy, physics education, physics and environmental problems, etc.

The political transformation since 1989 has naturally influenced the Union and its Physical Section. Reduction in membership and in the amount of voluntary activity, the destruction of contacts with the industry, and an overall lack of funds have all had a negative impact on our work. We feel that new conditions badly need new approaches to almost everything, including the definition of the Section's role. Something similar must emerge in our relations with EPS. To be a member of EPS during the communist era was primarily seen as a manifestation of a link with Europe and the free, democratic world. Now that the barriers between west and east in Europe have been destroyed, this rationale has lost much of its original meaning and a new type of reasoning must appear. I hope, that this can be found in, for example, active support for full integration of Europe's physics community, with the emerging all-Europe union as the final goal.

\section{References}

[1] Mašek K. et al., Laser and Particle Beams 12 (1994) 445.

[2] Láska L. et al., Appl. Phys. Lett. 65 (1994), 691

[3] Mróz W. et al., Rev. Sci. Instr. 65 (1994), 1272

[4] Trejbal Z. et al., Proc. 13th Conf. Cyclotrons and their Applications

(Vancouver, Canada, July 1992) 465

[5] Šturza J. et al., Proc. Europ. Part. Conf. (Berlin,

Germany, 24-28 March 1992).

[6] Internal publn. of the Institute for Information in Education, Prague (1995).

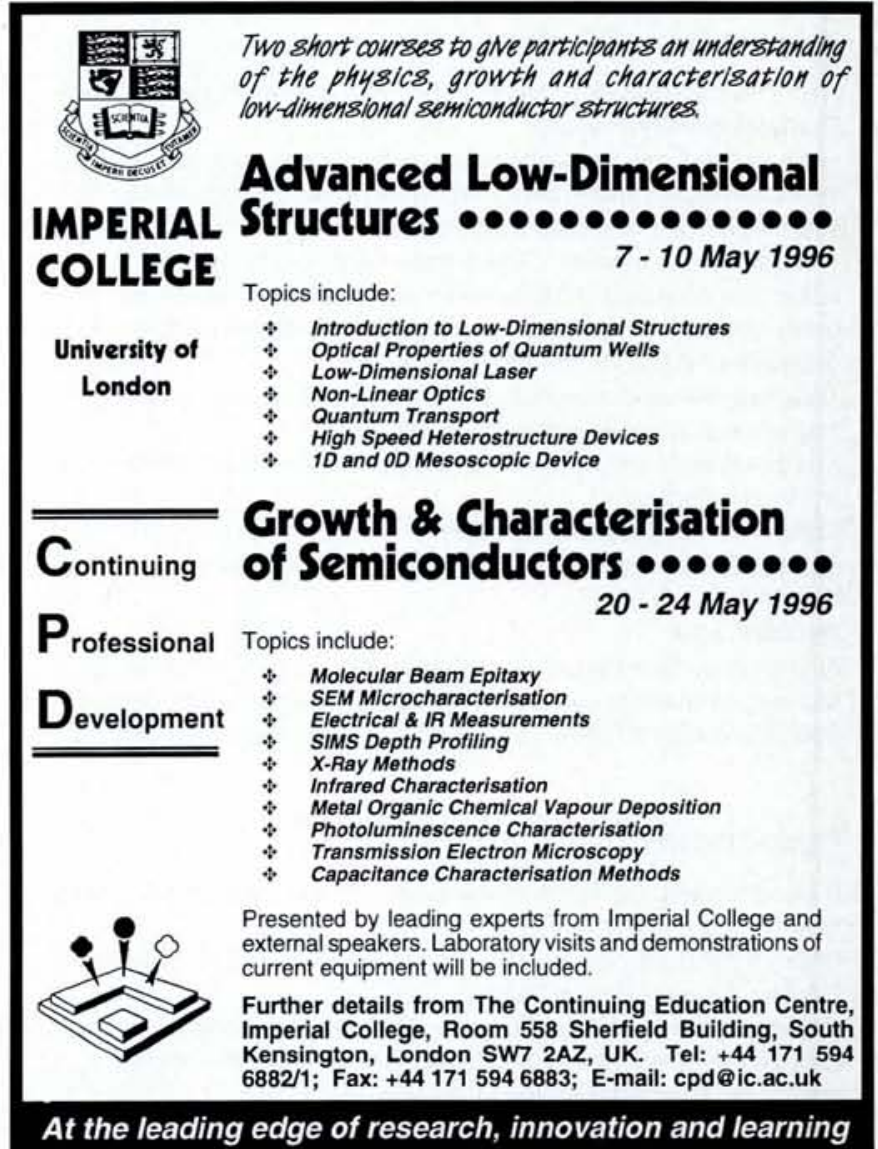

\title{
Union Matters
}

\section{More "Stimulation"}

Jacques Santer, the President of the European Commission (EC), in last November's state of the European Union (EU) address to the European Parliament, said that the EC will aim in 1996 "to stimulate more and legislate less" (it plans 26 major debates, 48 Action Plans and 19 new proposals for legislation). Major issues for science are the next Framework Programme ( $\mathrm{FP}_{5}$ ) and copyright in the information age.

\section{Science in Framework 5}

Edith Cresson, the EC science Commissioner, wants to follow the example of the EU's main industrial competitors by concentrating $\mathrm{FP}_{5}$ on a few selected areas of marketoriented research. The EC will examine task-force reports so that in the second-half of 1996Ministers can suggest where best to concentrate future research.

As part of the debate on $\mathrm{FP}_{5}$, the European Science Foundation has sought input from member organizations. The Royal Society's Council recently endorsed a working-group submission that stresses the need for more basic research in $\mathrm{FP}_{5}$ than in $\mathrm{FP}_{4}$, especially outside the basic-science oriented Training and Mobility of Researchers programme (it proposes not less than $10 \%$ of the FP5 budget). For if basic research is starved, "productive applied research will wither within a decade". Moreover, as research becomes more sophisticated, and more expensive, there is a tendency for "less support in areas of basic science with unpredictable or, at best, long-term returns".

\section{Framework 4 Reserve}

The main item on the EU's immediate research agenda is clearly whether to release the 700 MECU reserve that was allocated to the present $\mathrm{FP}_{4}$. Edith Cresson wants to start using the funds, but this could push EU spending above the ceiling agreed by Ministers in 1992. Moreover, the EU has since committed itself to helping rebuild the Balkan region. Ministers will need to agree on priorities before approaching the Parliament.

\section{Balanced Cooperation}

The EC has said in a communication on international cooperation in research and technological development that "the key task for future policies is to establish a

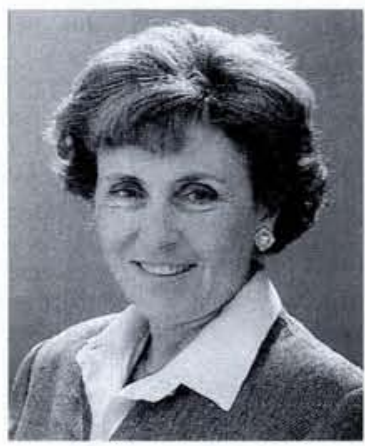

Edith Cresson visited Israel in January to mark the EU's first comprehensive bilateral science agreement. beneficial balance between competition and cooperation". To balance possible job losses with increased markets, it seeks worldwide cooperation in science "to share risk and effort". It also says that the EU "now has an increased responsibility to ensure a stable environment in a wider Europe" where cooperation in science can "upgrade the economic potential of its neighbours".

The EU signed its first comprehensive bilateral cooperation agreement in science last October. It is with Israel, which is called a "non-European thirdcountry", and by contributing close to 100 MECU for 1996-7, the country's scientists can participate in $\mathrm{FP}_{4}$ non-nuclear $\mathrm{R} \& \mathrm{D}$ programmes and in management committees (without votes). Other agreements, e.g., with Canada and Australia, are for a project-byproject basis. Negotiations are expected to start soon on comprehensive agreements with the US, Japan and South Africa. 